\title{
Monetary and informational form of capital as the basis of investment support for the inter-phase transition to an innovative economy
}

\author{
Oksana Butorina*, and Yulia Starodumova \\ Perm National Research Polytechnic University, 29 Komsomolsky prospect, Perm, 614990, Russian Federation,
}

\begin{abstract}
Abstarct. Within the framework of the identified predominant processes that form the uniqueness of inter-phase transitions, the article highlights the accumulating processes of system transformation. At the same time, within the framework of the transition from the neo-industrial to the digital economy, informatization as a conjunctural process, based on the mass introduction of digital technologies, contributes to the formation of the monetary and information form of capital. Based on the analysis of the definitions of monetary and informational forms of capital, two approaches can be identified. The first of them is narrow, from his point of view, the MIFC is investment resources in real assets through digital and IT technologies. The second approach is broad, it allows us to interpret MIFC as an independent form of capital associated with the self-increasing cost of investments in the development of information and labor resources to create new high-tech products that can increase surplus value at each intra-phase transition of the post-industrial megacycle.
\end{abstract}

\section{Introduction}

The current development of the national and global economy can be defined as a transformational period from industrial to post-industrial development. Its uniqueness is in the complex interweaving of processes characteristic of the final phase of the industrial megacycle and the nascent post-industrial megacycle. At the same time, the final cycle is called the industrial megacycle by us because its dynamics reflect the essential nature of the industrial era, its heyday fell on the period of domination of the II-IV technological order with a total time duration of more than 100 years (18351940), while starting from the 60s of the XX century, during the transition to the $\mathrm{V}$ technological order, the conditions for a new stage of the industrial economy neo-industrial, which is considered by us as the final stage of the industrial era, was formed.

We define the postindustrial megacycle similarly as a cycle associated with the formation and development of a post-industrial society and its economy. As the authors point out they are characterized by the following processes:

- the production of services is of priority importance, which is associated with its ability to form a larger surplus product than the industrial "core";

- the importance of information as an economic resource increases significantly, it becomes the main transformative production resource;

- the formation of profit largely depends not on the efficiency of the production sector, but on the effectiveness of intellectual and managerial activities;
- increasing the importance of the human factor as a resource that can accumulate information and create new knowledge;

- the predominance of venture capital businesses that can quickly adapt to changing business conditions and consumer preferences, functioning "ahead of the curve";

- introduction of new forms of investment support for economic development.

The processes outlined above are the cross-cutting nature, and they manifest themselves with varying degrees of intensity in each phase of the post-industrial cycle.

\section{Results}

Previously published works of the authors proved that the post-industrial megacycle can include the phases of the classical four-phase cycle, each of which is characterized by a corresponding transition from one type of economy to another. It should be particularly noted that in each phase, processes are formed and developed that give uniqueness to the interphase transition within the post-industrial megacycle. Thus, transition from neo-industrial to digital economy (Depression phase) characterized by science-intensive technotronic industrialization of the economy, based on the creation of new forms of business, markets, and consumers, supported by the technological capabilities of the digital economy; comprehensive renewal and transformation of productive forces based on digital technologies in the areas of electronic document management, electronic accounting systems, electronic

Corresponding author: ok.butorina@yandex.ru 
data warehouses, the use of GRM, the creation of corporate social networks, the expansion of the use of ICT in production as part of the automation process, robotization, computerization, in management, communication and entertainment, as well as in the field of electronic payment systems in the framework of ecommerce [14, 18]

Recovery phase (transition from digital to innovation and information economy) характеризуется informatization and innovatization of the economy and society as a whole, based on the venturization of business, the formation of the monetary and information form of capital, large-scale commercialization and socialization of information, the continuous mass generation of innovations, significant changes in the structure of the economy, based on the growth of the share of neo-industrial, innovative, information RCTEA $[10,11]$

Lifting phase (transition from innovation and information economy to neo-economy) характеризуется informatization, generation of knowledge and innovations with a strong feedback between innovations and directions of their use, assuming the priority of information as an economic resource, individualization of knowledge, generating the importance of the information sector in the innovative development of national and global economies, globalization of business, investment and labor flows [7, 9, 12]

Based on the presented table, the following conclusions can be drawn:

The third is that modern development can be characterized by a transition from the neo-industrial to the digital economy, the completion of which can be determined by increasing the efficiency of production by optimizing costs and increasing profitability, expanding the range of benefits created in the field of virtual and digital economy, the beginning of structural changes in the economy - increasing the share of the neo-industrial sector in the created national wealth, transformation of the dynamics and income structure of all participants in the production process.

If we take into account the presence of recurrent dependencies between processes that also have a cyclical nature, within the framework of the transition from the neo-industrial to the digital economy, we can assume that informatization as a conjunctural process, based on the mass introduction of digital technologies, contributes to the formation of the monetary and information form of capital.

Of particular note is the lack of unity of interpretations of the concept of "monetary and informational form of capital", which required a more detailed differential analysis of the components of this definition. In the most general form, capital is considered to be money that can generate income (in other words, it is money that performs the function of accumulation). Depending on the source of accumulation (the possibility of increasing), it is customary to allocate different forms of capital. Despite all the variety of forms in the framework of this work, the priority of the research was given to monetary and informational forms.

Next, we will present the most common definitions of the monetary form of capital in the modern economic literature:

- the common denominator to which the cost of capital in the form of any asset is made. In monetary terms, the value of both physical and human capital is formed. Monetary capital, or capital in monetary form, is an investment resource. By itself, monetary capital is not an economic resource, it does not directly participate in production, and it is used to buy factors of production [19];

- one of the components of economic capital, based on the realization of the objectified material state in the form of financial resources [13];

- this is money intended for the acquisition of physical capital, in other words, invested in the business, a working source of income in the form of means of production: machinery, equipment, buildings, structures, land, stocks of raw materials, semi-finished products and finished products used for the production of goods and services [16].

To concretize the author's definition of the monetary and informational form of capital, we consider it appropriate to compare the most well-known interpretations of information capital:

- this is the accumulated investment in the IT sector, technological, scientific and technical, socio-economic and spiritual information used to generate income (technology is the basis of this capital) [19].

- a new form of intellectual capital associated with the formation of information and communication technologies. It acts as a new self-increasing value, characterizes the efficiency of the use of production factors, among which the most important is the intellectual resource. New knowledge is being created, and a new system of economic relations is being formed within the framework of the digital economy [3];

- a special form of expression of intellectual capital, characterizes the process of accumulation and dissemination of information and experience, the development of socio-economic foundations for the dissemination and transfer of knowledge. Information capital becomes the core of the "knowledge management" system, which leads to the creation of corporate universities and centers of scientific and technical information, and the transformation of organizations into self-learning systems [4];

- this is the available capital of organizations that implement information services [21];

- this is a part of non-financial assets associated with the formation of certain information resources [2, p. 46];

- this is a set of renewable information resources that simultaneously act as a capitalized stock and flow, which have a consumer and commercial value and bring income to their owner when involved in economic turnover [6, p. 13];

- these are databases, information systems that provide knowledge routing and rapid implementation of new developments [5, p. 10];

- these are information systems, technologies, 
infrastructure, and an IT resources management system that are necessary for the implementation of the strategy [1, p. 10];

- these are databases, information systems, communications, and technologies. The basis of information capital is business applications, infrastructure and services $[17$, p. 221];

- intangible capital, which includes: knowledge capital, human capital, organizational capital $[6$, p. 136153];

- this is capital, which includes technological, scientific and technical, social and economic, spiritual information used in economic turnover to generate income [6]

Based on the presented table, when determining the essence of the monetary and information form of capital (MIFC), two approaches can be distinguished. The first of them is narrow, from his point of view, the MIFC is investment resources in real assets through digital and IT technologies. According to I. N. Sokolov, these include crowdfunding, crowdlending, crowdinvesting and P2P lending, and other alternative financing platforms [15].

According to financial analysts, these platforms are essentially an alternative financial tool for attracting capital to startups and small businesses from a wide range of micro-investors.

Crowdfunding is a type of investment that is very similar to charity. For the money invested in the project, you get some kind of gift or privilege. For example, you may be sent a thank-you letter, sent a product under development before the official start of sales, or given a lifetime discount on the purchase of the product. The bonus depends on the imagination and capabilities of the person who raises money for his product [20].

Crowdlending is already investment-lending. Through the financial platform, you "credit" the entrepreneur. With this type of investment, the profit can reach up to $30 \%$ per annum.

There are two types of crowdlending:

p2p-lending ("peer to peer") - an individual lends to an individual

p2b-lending ("peer to business") - an individual lends to a company (legal entity)

Crowdlending is very convenient for business, money is provided without bail and with an interest rate lower than the bank rate.

One of the most popular platforms for crowdlending abroad is Lendingclub.com. In Russia, the Town of Money (townmoney.ru) and Stream (investor. potok. digital) are known [20].

Crowdinvesting is lending to small businesses. If a company that needs investment has shares, then it makes each investor its own shareholder. If the company does not have shares, then the investor is offered other options for registering a share in the company. This financial instrument combines the advantages of both crowdlending and venture capital investment, since by distributing the "loan" necessary for the company among several donors, the chance of collecting the final amount increases.
A well-known global platform for crowdinvesting is Crowdcube.com. The Russian equivalent is Starttrack.ru [20]

The second approach is broad, it allows us to interpret MIFC as an independent form of capital associated with the self-increasing cost of investments in the development of information and labor resources to create new high-tech products that can increase surplus value at each intra-phase transition of the post-industrial megacycle.

\section{Discussion}

The presented author's definition of the MIFC allowed us to present the process of creating self-increasing value as follows:

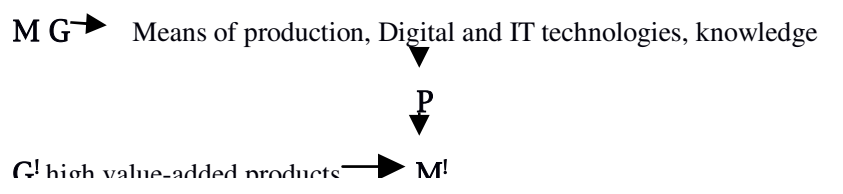

The connection at the first stage of the cycle the creative personality with information and communication technologies and other information resources leads to the possibility of creating new products that have the properties of innovation. The production of such products at the second stage of the cycle (the production stage of the information capital cycle) is associated with the creation of a new product with special information properties that have a high added value.

The essence of the functioning of the MIFC allowed us to identify its additional properties:

- the existence of an accumulation effect that occurs after a certain time period;

- relatively lower mobility compared to other forms of capital;

- the need for permanent improvement of its quality content;

- a high level of personification associated with a person as a basic carrier and translator of information;

- accumulation of technical, economic, organizational, technological and managerial content in it;

- its manifestation in the process of production of final goods is the costs of production and labor costs;

The implementation of the essence of the MIFC and its distinctive features allowed us to specify the conditions for the formation and development of the MIFC.

- increasing competition between global producers in the field of information and communication technologies;

- the need for reorganization;

- development of competition between manufacturers of innovative products;

- increasing the role of information and communication technologies in economic development 
based on the creation of appropriate infrastructure;

- improvement of the regulatory system in the field of digital economy [4.].

It should be particularly noted that the large-scale use of MIFC can help accelerate the transition from the industrial era to the information and innovation phase of the post-industrial megacycle based on:

- increments of knowledge, when scientific knowledge and unique experience and special skills of a person become the main factor for ensuring economic growth and sustainable economic development;

- ensuring the stability of the reproduction process at all levels of the economic system;

- formation of new global investment flows;

- introduction of new financial institutions based on digital and IT technologies.

\section{Conclusions}

Thus, within the framework of the prevailing processes that form the uniqueness of inter-phase transitions, we can distinguish the accumulating processes of system transformation, such as: general informatization, structural transformation, innovatization, capitalization of labor resources, service production, science-intensive transformation of productive forces, the formation and mass use of new forms of investment support for economic development. At the same time, within the framework of the transition from the neo-industrial to the digital economy, informatization as a conjunctural process, based on the mass introduction of digital technologies, contributes to the formation of the monetary and information form of capital. Based on the analysis of the definitions of monetary and information forms of capital, two approaches can be distinguished in determining the essence of the monetary and information form of capital (MIFC). The first of them is narrow, from his point of view, the MIFC is investment resources in real assets through digital and IT technologies. These may include crowdfunding, crowdlending, crowdinvesting, and P2P lending, as well as other alternative financing platforms. The second approach is broad, it allows us to interpret MIFC as an independent form of capital associated with the self-increasing cost of investments in the development of information and labor resources to create new high-tech products that can increase surplus value at each intra-phase transition of the post-industrial megacycle. The essence of the functioning of the MIFC allowed us to identify its additional properties:

1) the presence of the accumulation effect that occurs after a certain time period;

2) relatively lower mobility compared to other forms of capital;

3) the need for permanent improvement of its qualitative content;

4) a high level of personification associated with a person as a basic carrier and translator of information;

5) accumulation of technical-economic, organizational-technological and managerial content in it;

6) its manifestation in the process of production of final goods is the costs of production and labor costs.

\section{References}

1. G. Astratova, E. Burnasheva., V. Shupletsova Information capital and its evaluation. Marketing Research Company Retrieved from: http://www.kpilib.ru/article.php?page $=325$

2. V. Bauchenkov Economic and Humanitarian Sciences, 8 (2014)

3. Yu. Bashin Bulletin of the Moscow State University of Instrument Engineering and Informatics. Series: Socio-economic sciences, 18 (2009).

4. A. Bushuev, L. Lezhenina Science studies, 4 (2012)

5. A. Zinovev Development of innovative activity of the enterprise on the basis of management of intangible assets: $\mathrm{PhD}$ dissertation (Moscow, 2007)

6. S. Dyatlov, T. Scientific Works of DonNTU. Series: economic 103-1 137-143, (2018), Zyablyuk, N. Titova Bulletin of the Moscow University, 6, 2 (2016)

7. Yu. Korechkov, L. Lezhenina Bulletin of Eurasian Science, 3 (2018)

8. Economic theory on the threshold of the XXI century: Neoeconomics. (Moscow: Yurist. 2001).

9. R. Nizhegorodtsev The Economy of Innovation (Moscow: Ruscience, 2016)

10. P. Lemeshchenko Neoeconomics: subject certainty and theoretical contours Retrieved from: https://www.bsu.by/Cache/pdf/351783.pdf

11. Ya. Popova News and Society. Economy. Retrieved from: http://fb.ru/article/33482/innovatsionnayaekonomika

12. V. Radaev, Economic Sociology, 4 (2002)

13. T. Romanova Digital Economy in Russia Retrieved from: http://fb.ru/article/334484/tsifrovayaekonomika-v-rossii.

14. I. Sokolov, Pravo. Management. Marketing, 1 (2018)

15. Reference book Retrieved from: //https://spravochnick.ru/ekonomika/kapital/.

16. R. S. Kaplan, D. P. Norton M. Pavlova. Strategic maps: transformation of intangible assets into tangible ones (Moscow: OlympBusiness, 2007)

17. I. A. Sushkova The transition of Russia to a neo-industrial model of economic development in modern conditions Retrieved from:: http://vuzirossii.ru/publ/neoindustrialnoj_mode $\underline{\text { li/34-1-0-5341 }}$ 
18. Financial analysis Retrieved from: https://1fin.ru/?id=281\&t=1372

19. O. Chulanova Materials of Afanasiev readings. 1 (18), (201)7.

20. N. Shitukhina, Scientific Bulletin of the SIM, 2, (2018) 